\title{
Low molecular weight heparin prophylaxis: a boon for women with history of placental mediated complications
}

\author{
Shweta Singh ${ }^{1 *}$, Renuka Sinha $^{1,2}$, Mayank Kaushik $^{3}$ \\ ${ }^{1}$ Department of Obstetrics \& Gynaecology, V.M.M.C. \& Safdarjang Hospital, New Delhi, India \\ ${ }^{2}$ Department of Obstetrics \& Gynaecology, Rama Medical College, Ghaziabad, Uttar Pradesh, India \\ ${ }^{3}$ Department of Dermatology, MMIMSR, Ambala, India \& E.S.I.C Basaidarapur, Delhi, India
}

Received: 24 December 2014

Accepted: 11 January 2015

\section{*Correspondence: \\ Dr. Shweta Singh, \\ E-mail: dr.s.singh.2@gmail.com}

Copyright: $(\mathbb{C}$ the author(s), publisher and licensee Medip Academy. This is an open-access article distributed under the terms of the Creative Commons Attribution Non-Commercial License, which permits unrestricted non-commercial use, distribution, and reproduction in any medium, provided the original work is properly cited.

\begin{abstract}
Background: Prevention of placental mediated pregnancy complication is likely the best approach to decrease maternal mortality and morbidity. Anticoagulation therapy represents a good preventive option.

Methods: A prospective randomized case control study was conducted at Safdarjang hospital. Patients were recruited from Sept. 2011 till May 2012 and followed till delivery. Thirty cases \& controls were enrolled which comprised of non- thrombophilic patients with previous history of severe preeclampsia, Fetal Growth Restriction (FGR), severe placental abruption, stillbirth after 20 weeks. Study group received LMWH according to weight subcutaneously, once daily started at $<15$ weeks till 36 weeks of gestation. Maternal outcomes were observed in both groups.

Results: Incidence of stillbirth and abruption were significantly lower in study group ( 0 versus $3.3 \%, \mathrm{P}=0.05$; and 0 versus $20 \%, \mathrm{P}=0.01)$. The respective incidence of severe preeclampsia and FGR were $6.6 \%$ versus $40 \%(\mathrm{P}=0.04)$ and $6.6 \%$ versus $30 \%(P=0.02)$. There was reduction of $72.7 \%$ of total adverse outcome.

Conclusions: Prophylactic LMWH before 15 weeks of gestation decreases the incidence of placental mediated complications in non thrombophilic pregnant women who had previously suffered with these complications.
\end{abstract}

Keywords: Low molecular weight heparin, Preeclampsia, Abruption, Stillbirth, Fetal growth restriction

\section{INTRODUCTION}

Placental thrombosis leads to severe pregnancy complications such as preeclampsia, still birth, foetal growth restriction and abruption. ${ }^{1-4}$ This is due to placental vasculopathy and abnormal placental attachment which leads to decreased placental perfusion. ${ }^{5-7}$ Several studies have reported these placental mediated complications even in patients without thrombophilia. ${ }^{8}$ Among different etiologies responsible for complicated pregnancies, abnormal placentation is one of the important factors. Prevention of placental mediated pregnancy complications is the best approach to decrease the maternal and mortality and morbidity. Since thrombosis in the uteroplacental circulation is frequently observed in placental-mediated pregnancy complication ${ }^{9}$ and pregnancy being a prothombotic condition, prophylactic anticoagulation therapy represents a good preventive option.

Low Molecular Weight Heparin (LMWH) treatment has been recommended for pregnant women with history of adverse pregnancy outcome and who have been diagnosed as thrombophilic. It has been observed that placental vasculopathy is similar for both thrombophilic and non thrombophilic patients. ${ }^{5-7}$ LMWH exerts it anticoagulating effect by activating Anti Thrombin (AT) factor. In addition to anti coagulation benefits of LMWH on placenta, it also exerts a direct stimulatory effect on angiogenesis and also increases vascular permeability. ${ }^{10}$ 
It also inhibits proliferation of vascular smooth muscles ${ }^{11}$ which helps in adequate perfusion to fetus through placenta.

Only a few studies have been reported till date and none of them have been done on Indian women. So a pilot study was designed to examine the effect of LMWH on non thrombophilic pregnant women who had severe placental mediated pregnancy complications in previous pregnancy. The present study was conducted to observe the role of LMWH in preventing the recurrence of severe placental mediated pregnancy complication in pregnant women, who had negative results for inherited and acquired thrombophilia in earlier pregnancies.

\section{METHODS}

The present study was a randomized prospective case control study done at department of Obstetrics and gynaecology, V.M.M.C \& Safdarjang hospital, New Delhi. Patients were recruited from September 2011 till May 2012 and followed up till delivery.

\section{Inclusion criteria}

- Women of age group $\geq 18$ years, willing to participate.

- History of $(\mathrm{H} / \mathrm{o})$ severe preeclampsia in previous pregnancy defined as high blood pressure (two separate readings taken at least six hours apart of 140/90 or more) and $300 \mathrm{mg}$ of protein in a 24-hour urine sample (proteinuria) and severe preeclampsia is diagnosed when BP is over $160 / 110$ and $>3 \mathrm{gm}$ of proteinuria.

- OR H/o fetal growth restriction in previous pregnancy defined as weight below the 10th percentile for its gestational age.

- OR H/o severe placental abruption.

- OR H/o stillbirth after 20 weeks in previous pregnancy

- Gestational age $<14$ weeks.

- $\quad$ Thrombophilia screen - negative (including)

- Anticardiolipin antibody

- Lupus anticoagulant

- $\quad \beta 2$ glycoprotein

- Protein C \& protein S

- Leiden actor V

- Anti-thrombin III

\section{Exclusion criteria}

- Multiple pregnancy
- History of losses due to anatomic, chromosomal, endocrine or immunological causes

- $\mathrm{H} / \mathrm{O}$ arterial or venous thrombosis or thrombophilic disorder.

- Women were already known to have anti phospholipid antibody.

- Previous $\mathrm{h} / \mathrm{o}$ infertility ( $\geq 3$ early miscarriage)

- Maternal HIV, Cytomegalovirus virus, Toxoplasma virus.

- Allergy to heparin or LMWH

- H/O diabetes, hyperthyroidism, chronic renal insufficiency.

Pregnant women who were having history of placental mediated complication were screened for thrombophilia screen and those who were fulfilling the inclusion criteria were included. All females were given a serial number and then randomization was done by using random number table and labelled as cases and controls. Ethical clearance was obtained from ethical committee of V.M.M.C \& Safdarjang Hospital. Out of 60 pregnant females, 30 women who were included in study group \& rest 30 were labelled as control.

Study group received LMWH (Enoxaparin Sodium) depending upon their body weight $(<50 \mathrm{~kg}=20 \mathrm{mg} ; 50$ $90=40 \mathrm{mg}$ and $>90 \mathrm{~kg}=60 \mathrm{mg}$ ) subcutaneously, once daily initiated between 11 and 15 weeks of gestation and continued up to 36 weeks of gestation. Control group were given placebo injections of Normal Saline. Both the groups were monitored by the same observer for development of any pregnancy related complications. Full blood counts and coagulation profile was done at 7 to 10 days after commencement of treatment and then repeated at $28 \& 36$ weeks. Along with that monthly ultrasound scan to assess the fetal growth and placental maturity was done. Also trimester wise Doppler was done to assess uteroplacental blood flow by studying resistance index and pulsatility index in uterine and umbilical artery. All cases and control were given intensive antepartum, intrapartum and postpartum care in the hospital and maternal outcome was observed.

\section{Statistical analysis}

All data was recorded in a masterchart and was analysed using SPSS version 16.0. Student' $t$ ' test was used to compare demographic data between two groups and Chi square test was used for categorical data. Fisher exact test and Mann Whitney tests were used as and when applicable. $\mathrm{P}$ value $<0.05$ was considered statistically significant. 


\section{RESULTS}

In the present study, $56.7 \%$ were between the ages of 25 to 29 years while $30 \%$ of the study population was less than 25 years. Similarly majority of controls belonged to age group range of 25-29 years while $16.7 \%$ were below 25 years (Table 1$)$. There was no difference in the rate of each adverse effect for the previous pregnancy between the two groups (Table 2).

Table 1: Age wise distribution of cases and control.

\begin{tabular}{|c|c|c|c|c|c|}
\hline \multirow[b]{2}{*}{ Group } & & \multicolumn{3}{|c|}{ Age group } & \multirow[b]{2}{*}{$\begin{array}{l}\text { P } \\
\text { value }\end{array}$} \\
\hline & & $\begin{array}{l}<25 \\
\text { years }\end{array}$ & $\begin{array}{l}25-29 \\
\text { years }\end{array}$ & $\begin{array}{l}\geq \mathbf{3 0} \\
\text { years }\end{array}$ & \\
\hline \multirow[b]{2}{*}{ Cases } & Count & 9 & 17 & 4 & NS \\
\hline & $\begin{array}{l}\% \text { within } \\
\text { group }\end{array}$ & $30.0 \%$ & $56.7 \%$ & $13.3 \%$ & \\
\hline \multirow[b]{2}{*}{ Control } & Count & 5 & 23 & 2 & NS \\
\hline & $\begin{array}{l}\text { \% within } \\
\text { group }\end{array}$ & $16.7 \%$ & $76.7 \%$ & $6.7 \%$ & \\
\hline
\end{tabular}

Table 2: Adverse outcomes in study and control group before treatment.

\begin{tabular}{|c|c|c|c|}
\hline & $\begin{array}{l}\text { Cases } \\
n=30\end{array}$ & $\begin{array}{l}\text { Control } \\
n=30\end{array}$ & $\begin{array}{l}P \\
\text { value }\end{array}$ \\
\hline Stillbirth [n (\%)] & $14(46.7 \%)$ & $14(46.7 \%)$ & NS \\
\hline $\begin{array}{l}\text { Preeclampsia mild } \\
{[\mathrm{n}(\%)]}\end{array}$ & $0(0 \%)$ & $1(3.3 \%)$ & NS \\
\hline $\begin{array}{l}\text { Preeclampsia } \\
\text { severe }[\mathrm{n}(\%)]\end{array}$ & $11(36 \%)$ & $14(46.6 \%)$ & NS \\
\hline Abruption [n (\%)] & $7(23.3 \%)$ & $6(20 \%)$ & NS \\
\hline IUGR [n (\%)] & $11(36.7 \%)$ & $14(46.7 \%)$ & NS \\
\hline
\end{tabular}

During the study, none of the cases had stillbirth while $3.3 \%$ women in control group had stillbirth. Forty percent of control during the study developed severe preeclampsia while $<7 \%$ of cases had the same. None of cases developed abruptio but 2 patients developed IUGR. The corresponding figure in control was 6 and 9 patients respectively (Table 3 ).

Table 3: Association between adverse outcome in case and control after treatment.

\begin{tabular}{|llll|}
\hline Stillbirth [n (\%)] & $\begin{array}{l}\text { Cases } \\
\mathrm{n}=30\end{array}$ & $\begin{array}{l}\text { Control } \\
\mathrm{n}=30\end{array}$ & $\begin{array}{l}\mathrm{P} \\
\text { value }\end{array}$ \\
\hline $\begin{array}{l}\text { Preeclampsia mild } \\
\text { [n (\%)] }\end{array}$ & $3(10 \%)$ & $1(3.3 \%)$ & 0.5 \\
\hline $\begin{array}{l}\text { Preeclampsia } \\
\text { severe [n (\%)] }\end{array}$ & $2(6.6 \%)$ & $12(40 \%)$ & 0.04 \\
\hline Abruption [n (\%)] & $0(0 \%)$ & $6(20 \%)$ & 0.01 \\
\hline IUGR [n (\%)] & $2(6.6 \%)$ & $9(30 \%)$ & 0.02 \\
\hline
\end{tabular}

In current study it was observed that it $40 \%$ controls were started on anti-hypertensive while $10 \%$ of study population needed the therapy during study. During our study $60 \%$ developed skin reaction due to subcutaneous injection none had evidence of thrombocytopenia. None of them required any major treatment (Table 4).

Table 4: Comparison of use of anti-hypertensive and complications among cases and controls.

\begin{tabular}{|llll|}
\hline $\begin{array}{l}\text { Use of anti- } \\
\text { hypertensive }\end{array}$ & Number & Percentage & P value \\
\hline Cases & 3 & $10 \%$ & 0.008 \\
\hline Control & 12 & $40 \%$ & \\
\hline Complications & $\begin{array}{l}\text { Skin } \\
\text { reaction }\end{array}$ & $\begin{array}{l}\text { Placental } \\
\text { collection }\end{array}$ & $\begin{array}{l}\text { Thrombo- } \\
\text { cytopenia }\end{array}$ \\
\hline Cases [n (\%)] & $18(60 \%)$ & $1(3.3 \%)$ & 0 \\
\hline Control [n $(\%)]$ & 0 & 0 & 0 \\
\hline
\end{tabular}

\section{DISCUSSION}

\section{Main finding}

The mean age calculated in the study group was 26.2 years while that in control was 26.3 years. The study and control group were comparable as difference of ages was statistically not significant.

While including cases and control in the study, care was taken that both the groups were comparable in previous placental mediated complication. With prophylactic dose of LMWH, there was decrease in incidence of placental mediated complication in non thrombophilic population, when it was started at $<15$ weeks of gestation. A reduction of $72.7 \%$ of total adverse outcome was noticed. Reduction of $83.5 \%$ in preeclampsia, $80 \%$ in abruption and $78 \%$ in IUGR was also observed.

There were all live births in study group which indicated LMWH helped in improving the perinatal outcome by decreasing the ischemic lesions and infarction of placenta $^{13}$ and also by improving the utero placental blood flow.

During the antenatal period, incidence of preeclampsia was observed in $10 \%$ of cases \& $3.3 \%$ of control. However, incidence of severe preeclampsia in index pregnancy was significantly decreased as compared to control $(6.6 \%$ versus $40 \%, \mathrm{P}=0.04)$. It signified that LMWH helped in better placentation by having a direct stimulatory effect on angiogenesis and by its antiinflammatory action. ${ }^{14,15}$ Hence it prevented the progression of mild preeclampsia to severe preeclampsia.

None of the index pregnancy had placental abruption $(0 \%$ to $20 \% \mathrm{P}=0.0)$. While single patient had retro-placental collection of $1 \times 2 \mathrm{~cm}$ at 32 weeks, which was an incidental finding on USG. It resolved on its own and hence was not considered as an abruption. It suggested that LMWH by its anti-thrombotic effect decreases the chances of placental abruption. 
LMWH also decreased IUGR in study group $(6.6 \%$ versus $30 \% \mathrm{P}=0.02$ ) by preventing the thrombi formation. LMWH also improved placental vascularization due to its direct angiogenic effect. ${ }^{16}$ Thus better uteroplacental blood flow leads to decrease in growth restriction.

Incidence of total adverse outcome was significantly lower in study group (20\% versus $73.3 \%)$.

There was $75 \%$ reduction in intake of antihypertensive those who were on LMWH. Hence, it indicates that LMWH decreases the maternal morbidity related to drug intake.

LMWH is a safe drug as there were no major complications, hence holding an advantage in prevention.

These results were found consistent with the previous studies. Mello G et al. (2001-2002), ${ }^{14}$ who enrolled women with angiotensin-converting enzyme DD (a non thrombophilic state) with previous history of preeclampsia, in a randomized open-label study, observed the relative risk reduction of preeclampsia and severe growth restriction of $74.1 \%$ and $77.5 \%$ respectively. In treated women, the relative risk for preeclampsia was $0.26(\mathrm{P}=0.02)$ and the relative risk for fetal growth restriction was $0.14(\mathrm{P}=0.001)$.

Our results were also comparable with those of Rey E et al. $(2000-2007)^{8}$ in a controlled randomized study. This study observed a decrease in placental-mediated complications with the use of prophylactic doses of dalteparin which was started before 16 weeks of gestation. Total reduction of adverse outcome was from $23.6 \%$ to $5.5 \%$ and the relative risk reduction of $76.7 \%$ was observed by them.

In another retrospective cohort study by Kupferminc $M$ et al. $(2003-2007)^{12}$ decrease in the incidence of preeclampsia and placental abruption was observed (3.13\% cases versus $20 \%$ control , $\mathrm{P}=0.03$ : and 0 cases versus $15 \%$ control , $\mathrm{P}=0.03$ respectively). Incidence of fetal growth restriction was 6.25 versus $22.5 \%$. Overall adverse outcome was $9.4 \%$ versus $60 \%(\mathrm{P}=0.001)$.

Study done by Rey E et al. (2000-2007) ${ }^{8}$ noticed $20 \%$ of control needed antihypertensive and among cases it was only $12.7 \%$.

In previous studies also it was found there were no major complications.

Mello G et al. (2001-2002) ${ }^{14}$ did not observe any complication related to LMWH.

Rey E et al. (2000-2007) ${ }^{8}$ observed only 1 case with skin reaction due to dalteparin and no other major hemorrhage or heparin induced thrombocytopenia.

\section{Strength}

- $\quad$ LMWH does not require monitoring as it does not affect the prothrombin time (PT) or the INR

- It does not cross placenta so it does not affect foetus.

- This is one of its kinds in Indian sub-continent.

- This will help doctors in managing such patients who present with placental mediated complications.

- In-spite of small sample size result was encouraging.

\section{Limitation}

- $\quad$ Treatment is costly

- $\quad$ LMWH has to be administered daily so, requires approximately 300 total subcutaneous injections over the whole gestational period.

\section{CONCLUSION}

- LMWH prophylaxis in women with history of placental mediated complications with thrombophilia screen negative has positive maternal outcome. A total reduction of $72.7 \%$ of these complications was observed.

- A total reduction of $83.5 \%$ of preeclampsia, $80 \%$ of abruption and $78 \%$ of IUGR was observed.

- $\quad$ There were all live births in study group.

Funding: The study was funded by V.M.M.C and Safdarjang Hospital, New Delhi

Conflict of interest: None declared

Ethical approval: The study was approved by the ethics committee of V.M.M.C \& Safdarjang Hospital

\section{REFERENCES}

1. Kupterminc MJ, Eldor A, Steinman N, Mary A, BarAm A, Jaffa A, et al. Increased frequency of the genetic thrombophilia in women with complication of pregnancy. N Engl J Med. 1999;340:9-13.

2. Robertson L, Wu O, Langhorne P, Twaddle S, Clark $\mathrm{P}$, Lowe GD, et al. Thrombosis Risk and economic assessment of thrombophilia screening (TREATS) study. Thrombophilia in pregnancy: a systematic review. Br J Haematol. 2006;132:171-96.

3. Rodger MA. Thrombophilia and placenta mediated pregnancy complications: from the bench to bedside to policy. Thromb Res. 2009;123(Suppl 2):S100-4.

4. Rodger MA, Paidas M, McLintock C, Middeldorp S, Kahn S, Martinelli I, et al. Inherited thrombophilia and pregnancy complications revisited. Obstet Gynaecol. 2008;112:320-4. 
5. Many A, Schreiber L, Rosner S, Lessing JB, Eldor A, Kupferminc MJ. Pathological features of the placenta in women with severe pregnancy complications and thrombophilia. Obstet Gynaecol. 2001;98:1041-4.

6. Mousa HA, Alfirevic1 Z. Do placental lesions reflect thrombophilia state in women with adverse pregnancy outcome? Hum Reprod. 2000;15:1830-3.

7. Arias F, Romero R, Joist H, Kraus FT. Thrombophilia: a mechanism of disease in women with adverse pregnancy outcome and thrombotic lesions in the placenta. J Matern Fetal Med. 1998;7:277-86.

8. Rey E, Garneau P, David M, Gauthier R, Leduc L, Michon N, et al. Dalteparin for the prevention of recurrence of placenta mediated complications of pregnancy in women without thrombophilia: A pilot randomized controlled trial. J Thromb Haemost. 2009;7:58-64.

9. Oyelese Y, Ananth CV. Placental abruption. Obstet Gynaecol. 2006;108:1095-101.

10. Blajchman, MA, Young, E, Ofosu FA. Effects of unfractionated heparin, dermatan sulfate and low molecular weight heparin on vessel wall permeability in rabbits. Ann NY Acad Sci. 1989;556:245-54.

11. Greer IA. Thrombosis in pregnancy: maternal and fetal issues. Lancet. 1999;353(9160):1258-65.

12. Kupferminc M, Rimon E, Many A, Maslovitz S, Lessing JB, Gamzu R. LMWH versus no treatment in women with previous severe pregnancy complications and placental finding without thrombophilia. Blood Coagul Fibrinolysis. 2001;22:123-6.

13. Greer IA. Thrombosis in pregnancy: maternal and fetal issues. Lancet. 1999;353(9160):1258-65.

14. Mello G, Parvetti E, Fatin C, Riviello C, Gensini F, Marchionni M, et al. Low Molecular Weight Heparin lowers the recurrence rate of preeclampsia and restores physiological vascular changes in angiotensin-converting enzyme DD women. Hypertension. 2005;45(1):86-91.

15. Harenberg $J$, scheinder D, Heilmann L, Wolf $H$. Lack of anti-factor Xa activity in umbilical cord vein samples after subcutaneous administration of heparin or low molecular mass heparin in pregnant women. Haemostasis. 1993;23:314-20.

16. Leach RE, Kilburn BA Petkova A, Romero R, Armant DR. Diminished survival of human cytotrophoblast cells exposed to hypoxia/reoxygenation injury and associated reduction of heparin-binding epidermal growth factor - like growth factor. Am J Obstet Gynaecol. 2008;198(4):471.e1-7.

DOI: $10.5455 / 2320-1770 . i j r \operatorname{cog} 20150237$

Cite this article as: Singh S, Sinha R, Kaushik M. Low molecular weight heparin prophylaxis: a boon for women with history of placental mediated complications. Int J Reprod Contracept Obstet Gynecol 2015;4:210-4. 